\title{
Effect of supplementation on the performance of F1 crossbred goats finished in native pasture ${ }^{1}$
}

\section{Aloísio Monteiro de Carvalho Júnior ${ }^{2}$, José Morais Pereira Filho ${ }^{3}$, Rayana de Medeiros Silva ${ }^{2}$, Aderbal Marcos de Azevêdo Silva ${ }^{3}$, Marcílio Fontes Cezar ${ }^{4}$}

\author{
1 Projeto financiado pelo CNPq. \\ 2 Pós-Graduação em Zootecnia - Universidade Federal de Campina Grande (UFCG). \\ ${ }^{3}$ Departamento de Veterinária - UFCG. Pesquisador CNPq. \\ ${ }^{4}$ Departamento de Veterinária-UFCG.
}

\begin{abstract}
The present study aimed to assess the effect of supplementation on the performance of F1 (Boer $\times$ females of no defined breed) goats finished in native pasture. The experiment was conducted at the Universidade Federal de Campina Grande, Patos Campus, Paraíba, Brazil, with twenty-four 120-day-old non-castrated F1 (Boer $\times$ NDB) male goats, with a $15.52 \mathrm{~kg}$ live weight (LW). Animals were distributed in four levels of supplementation $(0.0 ; 0.5 ; 1.0 ; 1.5 \%$ of body) and six replicates. In order to perform the evaluation of dry matter availability, the herbaceous vegetation was divided into grass and herbaceous dicotyledon and evaluated at the beginning (5/28/2007), in the middle (7/9/2007) and at the end (8/6/2007) of the experiment. In the beginning of the experiment, the availability of grass dry matter was $1,102.89 \mathrm{~kg} / \mathrm{ha}$, and at the end of the experiment, the availability of the referred matter was greater $(1,494.81)$; on the other hand, the opposite occurred for the dicotyledons, with a dry matter content of $1,759.46 \mathrm{~kg} / \mathrm{ha}$ in the beginning of the experiment, and only $236.76 \mathrm{~kg} / \mathrm{ha}$ at the end of the experiment. Supplementation made it possible to estimate the increase in dry matter intake of $257.15 \mathrm{~g} /$ day and of $20.79 \mathrm{~g} / \mathrm{kg}^{0.75} /$ day, as well as the daily weight gain of $103 \mathrm{~g}$ for each percentage point increase that resulted from supplementation. The availability and nutritional quality of forage had a strong influence on the effect of supplementation on dry matter intake, with a negative response for supplementation levels of up to $0.74 \%$ of the live weight Consequently, the finishing of F1 crossbred goats in a grazing area in the Caatinga can be improved with the supplementation of concentrate at levels 1.0 to $1.5 \%$ of the live weight.
\end{abstract}

Key Words: caatinga, consumption, dicotyledons, digestibility, grass, weight gain

\section{Introduction}

The breeding of goats in native pasture lands is a common practice in the Brazilian Northeast. However, this pasture will not provide all the nutrients needed for the good health of the animals, particularly animals of breeds such as pure and crossbred Boers, which are expected to meet more specific and greater production requirements. According to Kanani (2006), for the effective use of native pasture, supplementation is needed in order to meet the nutritional demands of goats.

Concentrate supplementation can be an alternative method of feeding goats, although several aspects related to supplementation may bring undesirable results, such as the replacement effect characterized by the reduced forage consumption (Prohman et al., 2004).

On the other hand, the meat production segment that was focused on quantity is now more concerned with quality (Bonagurio et al., 2003), with the consumer more willing to have a greater quality of life. Thus, factors related to production and fat content of meat may be a determinant of the product's success in the market.

In this context, animals reared only in pasture areas have poor performance and reach slaughter weight at an older age, when their carcass is less marketable. In an attempt to solve this problem, many producers have moved to confinement systems. Nonetheless, the high cost of feed, particularly of corn and soybean meal-based diets may cause this practice to become unfeasible (Neiva et al., 2005). Another aspect that deserves consideration is that animals in lifetime confinement tend to have greater amounts of carcass fat, which may cause their meat to be rejected by the current market.

The system of production of goats for slaughter in native pasture with supplementation is an alternative method (Carvalho Júnior et al., 2009), especially for the small producer (Silva et al., 2010), because this system is aimed to combine quality with animal comfort. Therefore, the 
objective of the present study was to assess the effect of supplementation on the performance of $\mathrm{F} 1$ (Boer $\times$ females of no defined breed) goats finished in native pasture.

\section{Material and Methods}

The experiment was carried out at the Universidade Federal de Campina Grande (UFCG), Patos Campus, Paraíba, Brazil. The field stage was performed at the Núcleo de Pesquisa para o Desenvolvimento do Semiárido and the chemical analyses were performed at Laboratório de Nutrição Animal of UFCG. The 1.5 ha experimental area is located at the coordinates latitude S - $7^{\circ} 44^{\prime} 44.4^{\prime \prime}$, longitude $\mathrm{W}-37^{\circ} 16^{\prime} 28.5^{\prime \prime}$ and altitude of 262 meters.

The climate of the region, according to Köppen's classification is of type BShw' - semi-arid, with a short rainy season in summer-fall and rainfalls concentrated in the months of March and April, although the rainy season can also occur from January to May. The rainfall in the experimental period varied between 11 and $118.3 \mathrm{~mm}$. The average temperature varied from 26.6 to $29.4^{\circ} \mathrm{C}$, whereas the highest humidity index observed was $60 \%$ in the initial stage of the experimental period.

The soils covering small areas are irregularly shaped, and those classified as non-calcic brown and planosolic soils, with the occasional occurrence of dystrophic litosol, prevail.

The vegetation of the experimental area is characterized by native lignified species such as jurema-preta (Mimosa tenuiflora (Willd.) Poir.), marmeleiro (Croton sonderianus Muell. Arg.), catingueira (Caesalpinia bracteosa Tul.), cajarana (Spondias sp), juazeiro (Zizyphus joazeiro Mart.) and craibeira (Tabebuia caraíba Bur); and exotic species such as the algaroba (Prosopis juliflora (Sw) DC. and cajueiro (Anacardium occidentale), which, together, account for about 10 to $15 \%$ of the soil coverage. The main species that form the herbaceous stratum are grasses such as milhãs (Brachiaria plantagínea and Panicum sp.), capimbuffel (Cenchrus ciliares L), capim-rabo-de-raposa (Setaria sp.) and capim-panasco (Aristida setifolia H.B.K.) and dicotyledons, such as malva-branca (Cassia uniflora), alfazema-brava (Hyptis suaveolens Point), mata-pasto (Senna obtusifolia (L.) HS Irwin \& Barneby) and erva-deovelha (Stylozanthes sp.).

Twenty-four 120-day-old non-castrated F1 (Boer $\times$ females of no defined breed) male goats, with a 15.52-kg live weight were identified with antiparasitic earrings and collars and randomly distributed in 4 supplementation levels (0.0, $0.5,1.0,1.5 \%)$, totaling six replicates per treatment. Animals were kept in one single 1.5-ha plot enclosed by a wire netting and with availability of water and multi-mineral supplement during 98 days, with 14 days of adaptation and 84 days of experiment.

Animals were fed on a continuous grazing system from 7:30 a.m. to 4 p.m., and after this period they were taken to their stalls for supplementation in individual cages equipped with troughs and drinking vessels. Every 14 days after the beginning of the experiment, feces were examined for parasite load, and whenever the results indicated a load equal or higher than 500 eggs per gram (EPG) in the feces, an antiparasitic drug was administered. Animals were weighed every 14 days always at 7:30 a.m., 16 hours after fasting.

The experimental diet was composed of ground corn (53.21\%), wheat meal (24.43\%), cotton pie (13.61\%), soybean meal (3.76\%), soybean oil (1.75\%), limestone (1.5\%) and mineral core for goats (1.74\%). Diet was balanced according to AFRC (1998) recommendations so that the highest supplementation level provided a daily weight gain of $200 \mathrm{~g}$. The mineral core administered to the animals had the following percentage composition per kg of mineral: $130 \mathrm{~g}$ of Ca; 75g of P; $5 \mathrm{~g}$ of Mg; 1,500 mg of Fe; $100 \mathrm{mg}$ of Co; $275 \mathrm{mg}$ of CU; 1,000 mg of Mn; 2,000 mg of Zn; 61 mg of I; $11 \mathrm{mg}$ of Se; $14 \mathrm{~g}$ of S; $151 \mathrm{~g}$ of Na; $245 \mathrm{~g}$ of Cl; Max. $0.75 \mathrm{~g}$.

To evaluate the availability of dry matter, the herbaceous vegetation was divided into grass and herbaceous dicotyledons, and assessed in three periods: beginning (5/28/2007), middle (7/9/2007) and end (8/6/2007) of the experimental period. During each evaluation period, 20 samples were obtained for the estimates of the availability of dry matter (DM) of the components of the herbaceous stratum. Samples were made from North/South/East/west transects from the central point of the plot, and using a $1.00-\times 0.25-\mathrm{m}$ iron frame as sampling unit, according to a methodology recommended by Araújo Filho et al. (1991).

During each evaluation period, samples of grass and herbaceous dicotyledons were made, and these components were dried in a greenhouse, with the use of forced circulation for 72 hours, cooled at room temperature and ground for performing the analysis of dry matter (DM), crude protein, mineral material (MM), crude energy, neutral detergent fiber (NDF) and acid detergent fiber (ADF), according to the methodology described by Silva \& Queiroz (2002). The estimate of consumption was calculated from the combination of production of feces using the external indicator (LIPE) and the estimate of the indigestible fraction of the diet using the method for neutral detergent fiber (NDFi). The expressions recommended by Forbes (1995) were used for the estimate calculation. The concentration of LIPE in the feces was determined by infra-red spectroscopy. For NDFi determination, samples were 
introduced in the rumen of the goats through the ruminal fistula (Berchielli et al., 2000a).

The design was completely randomized, with four treatments and six replicates. In order to perform the analysis of performance in the different periods of time, a completely randomized design was used, with repeated observations, four treatments (supplementation level) and six observation periods. Data were submitted to variance and regression analyses at the 5\% probability level. Statistical data processing was done using the SAS (1999) statistical program.

\section{Results and Discussion}

Increase in grass content occurred as follows: in the beginning of the experiment (5/28/2007) there were $1,102.89 \mathrm{~kg} / \mathrm{ha}$ of dry matter (DM), which increased to $1,417.95 \mathrm{~kg} / \mathrm{ha}$ in the middle (7/9/2007), and reached $1,494.81 \mathrm{~kg} / \mathrm{ha}$ at the final stage of the experiment. As for the dicotyledons, its content increased from $(1,759.4)$ at the beginning of the experiment to the intermediate stage $(1,929.9)$ followed by increased reduction (236.7) at the end of the experimental period (Table 1 ).

The total availability of DM clearly indicates that dicotyledons increased from the beginning (5/28/2007) to the middle (7/9/2007) of the experiment and decreased at the final stage (8/6/2007) of the experiment. This increase in DM content that occurred from the beginning to the middle of the experimental period may be associated to rainfall, which was $71 \mathrm{~mm}$ in the month of May, 0.0 (zero) $\mathrm{mm}$ in June and only $10 \mathrm{~mm}$ in July. According to Araújo Filho et al. (2002), this fact may induce or cause physiological maturation in plants to occur earlier than expected, and, consequently, increase DM concentration.

The percentage of grasses increased throughout the experiment, with values of 38.53, 42.35 and $88.60 \%$ respectively in the beginning, middle and end of the experiment, whereas the opposite occurred with the dicotyledons, that is, their percentage was $61.47 \%$ in the beginning of the experiment, decreased to $57.65 \%$ in the middle of the experiment, and was merely $11.40 \%$ in the end. These results may indicate that goats grazed more on herbaceous dicotyledons than grasses. This was observed by Pereira Filho et al. (2007) in their study of the effect of alternating grazing with sheep and goats on the availability of phytomass of herbaceous stratum of low density caatinga vegetation, and the authors concluded that goat grazing increased the availability and participation of grass DM and reduced the herbaceous dicotyledonous content, and the opposite occurred with the paddocks occupied by the sheep.

One aspect that deserves consideration concerns the total availability of DM, which, even at the end of the experiment reached $1,731.57 \mathrm{~kg} / \mathrm{ha}$, reflecting the rainfall rates, the intense sunlight and the high temperatures during the rainy season, and these together maximized the growth of forage plants, increasing their availability and quality (Leão et al., 2005). Thus, Graham et al. (1993), in their research with sheep, affirm that when the availability of DM is more than three times greater than the amount needed by the animals and the digestibility of this dry matter is greater than 55\%, grazing can be effective and the animals can achieve high levels of performance.

The values obtained in the beginning of the experiment indicate the good quality of the forage with crude protein contents higher than the minimum $7 \%$ required for proper microbiologic development of the rumen, since the values were 9.8 and $12.42 \%$ for grasses and dicotyledons, respectively (Table 2). Two aspects must be considered regarding the values of the chemical composition: the first one is the relationship between the DM and crude protein composition following the rainfalls, which is demonstrated in the reduction of these contents from the beginning (May) to the middle (June) and end (July) of the experiment; the second aspect concerns the fact that the rainfalls $(10 \mathrm{~mm})$ at the end of the experiment might have positively influenced the dicotyledons, which sprouted again, and allowed lower contents of DM and a 13.43\% content of crude protein.

The digestibility values obtained with the use of NDFi, either grasses or dicotyledons, were greater than expected, varying from 60.62 to 67.27 for some grasses and from 57.64 to 70.78 in the dicotyledons (Figure 1). These values reflect in part the occurrence of rain throughout the experimental period, and the rain fall of $71 \mathrm{~mm}$ in May kept the forage

Table 1 - Availability of dry matter and floristic composition of grass and herbaceous dicotyledons in the beginning, middle and end of the experiment

\begin{tabular}{|c|c|c|c|c|c|c|}
\hline \multirow[t]{2}{*}{ Item } & \multicolumn{3}{|c|}{ Availability of dry matter $(\mathrm{kg} / \mathrm{ha})$} & \multicolumn{3}{|c|}{ Floristic composition (\%) } \\
\hline & Beginning & Middle & End & Beginning & Middle & End \\
\hline Grass & $1,102.89$ & $1,417.95$ & $1,494.81$ & 38.53 & 42.35 & 88.60 \\
\hline Dicotyledons & $1,759.46$ & $1,929.96$ & 236.76 & 61.47 & 57.65 & 11.40 \\
\hline Total & $2,862.36$ & $3,347.91$ & $1,731.57$ & 100.0 & 100.0 & 100.0 \\
\hline
\end{tabular}


green and productive; the lack of rainfall in June had little effect on the grasses, probably due to the resistance and phenology of the native grasses in the region, which was not observed in the dicotyledons; the rain fall of $10 \mathrm{~mm}$ in July must have favored the re-sprout of the dicotyledons, particularly the germination of those seeds which have already been thrown over the soil. This aspect, associated with the high selectivity of goats might have allowed a digestibility level around $70 \%$.

The DM intake (Tables 3 and 4) was influenced $(\mathrm{P}<0.05)$ by the levels of supplementation, with an increase of $257.15 \mathrm{~g}$ of $\mathrm{DM} /$ day, of $0.65 \%$ of crude protein, and $20.79 \mathrm{~g} / \mathrm{kg}^{0.75} /$ day g of DM for each percentage point increase that resulted from supplementation. This response contemplates in part the objective of providing

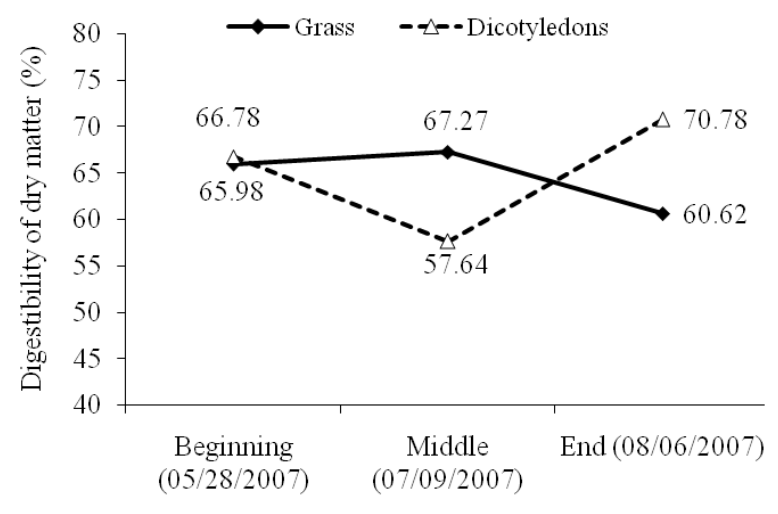

Experimental period

Figure 1 - Digestibility of dry matter of grass and herbaceous dicotyledons in the beginning, middle and end of the experimental period. supplementation at pasture, which is to increase the digestibility of the grazed plants, which in turn may result in better animal performance. Yet, Forbes (1995) calls attention to the need for assessment of the replacement effect, i.e., the replacement of consumption of large roughages with the intake of concentrate that might influence the economic response of supplementation.

Although the growing linear effect of supplementation is well characterized, it is important to stress that the greatest impact of DM intake expressed in g/day occurs between 1.0 and $1.5 \%$ of live weight (LW) supplement treatments, but when the DM intake is expressed in \% LW and in $\mathrm{g} / \mathrm{kg}^{0.75} /$ day, the greatest changes are observed between 0.5 and $1.0 \%$ treatments, and can be associated with different efficiencies of use of roughage and concentrate, particularly in the replacement of roughage with concentrate, which affected the performance of the animals.

The food conversion was not influenced by supplementation (Table 3); only the animals fed with supplement corresponding to $1.0 \%$ of $\mathrm{LW}$ gained one $\mathrm{kg}$ of LW while eating less than $5 \mathrm{~kg}$ of DM. An intake of 5.24, 5.41 and $6.21 \mathrm{~kg}$ of DM was necessary for the animals in the 0.0 , 0.5 and $1.5 \% \mathrm{LW}$ supplement treatments in order to gain $1 \mathrm{~kg}$ of LW.

Marques \& Belo (2001) stress that in addition to supplementation, the availability, palatability, structure, digestibility and botanical composition of forage, climate factors, availability of water, animal health and social behavior may influence animal intake. However, according to Waldo (1986) the use of concentrates in forage-based diets many times increases the total intake of DM, although

Table 2 - Chemical composition supplement used, grasses and dicotyledons in the beginning, middle and end of the experimental period

\begin{tabular}{|c|c|c|c|c|c|c|c|}
\hline \multirow[t]{2}{*}{ Item } & \multirow[t]{2}{*}{ Supplement } & \multicolumn{2}{|c|}{ Beginning } & \multicolumn{2}{|c|}{ Middle } & \multicolumn{2}{|c|}{ End } \\
\hline & & Grass & Dicotyledons & Grass & Dicotyledons & Grass & Dicotyledons \\
\hline Dry matter (\%) & 91.94 & 30.67 & 28.91 & 51.75 & 71.48 & 70.51 & 44.72 \\
\hline Mineral matter (\% dry matter) & 4.65 & 9.14 & 7.36 & 6.15 & 5.98 & 6.85 & 6.35 \\
\hline Crude protein (\% dry matter) & 14.55 & 9.8 & 12.42 & 4.35 & 8.29 & 5.71 & 13.43 \\
\hline Crude energy (Mcal/kg dry matter) & 4.65 & 4.21 & 4.21 & 4.14 & 4.27 & 4.16 & 4.57 \\
\hline Neutral detergent fiber (\% dry matter) & 23.22 & 77.51 & 60.60 & 79.64 & 66.35 & 80.31 & 67.12 \\
\hline Acid detergent fiber (\% dry matter) & 9.88 & 65.33 & 48.23 & 64.71 & 56.73 & 64.53 & 52.28 \\
\hline
\end{tabular}

Table 3 - Dry matter Intake and food conversion of goats finished on native pasture with different supplementation levels

\begin{tabular}{|c|c|c|c|c|c|c|}
\hline Item & \multicolumn{4}{|c|}{ Supplementation level (\% of live weight) } & Regression equation & $\mathrm{R}^{2}$ \\
\hline Dry matter intake (g/day) & 539.43 & 632.59 & 727.57 & 953.36 & $\hat{Y}=257.15 x+513.12$ & 0.95 \\
\hline Dry matter intake (g/ $\mathrm{kg}^{0.75} /$ day) & 50.43 & 58.01 & 74.26 & 79.66 & $\hat{Y}=20.788 x+49.999$ & 0.96 \\
\hline Conversion & 5.24 & 5.41 & 4.95 & 6.21 & $\hat{Y}=5.45$ & 0.34 \\
\hline
\end{tabular}

$\hat{\mathrm{Y}}=$ dependent variable; $\mathrm{x}=$ independent variable; $\mathrm{r}^{2}=$ coefficient of determination. 
it also promotes a reduction in relation to the consumption of forage. This fact was confirmed with the goats treated with supplements of $0.0,0.5,1.0$ and $1.5 \%$ of the $L W$, whose total intake of DM was increased from 539.43 g/day to 632.59, 727.57 and $953.36 \mathrm{~g} /$ day, with a consumption of forage of 539.43, 508.84, 510.07 and $530.86 \mathrm{~g}$ /day, for the same treatments, respectively (Table 4), characterizing a quadratic behavior, with the lowest consumption estimated when the supplementation level is $0.80 \%$ of $\mathrm{LW}$, which corresponds to a DM intake of 506.13 g per day (Figure 2), indicating the replacement effect (Figure 3).

Similar behaviors are reported in other ruminant species, as it can be seen in the study of Crabtree \& Williams (1971) with sheep in low quality pastures (3.9\% of crude protein) and supplemented with higher levels of concentrate. The authors noticed a quadratic effect, that is, increase in the consumption of forage up to $0.95 \%$ of LW; and Berchielli et al. (2000b), in their experiment with dairy cows in coastcross grass (Cynodon dactylon L.Pers.) pasture obtained a quadratic effect of up to 0.62 and $0.95 \%$ of the $\mathrm{LW}$ for Gir and Girolando cows, respectively.

The DM intake per animals in pasture is directly related to the availability and quality of forage. In their assessment of the availability of DM as a limiting factor in consumption and production of goats and sheep (Kabeya et al., 2002), Animut et al. (2005) worked with four paddocks and rotational occupation containing 4, 6 and 8 animals per plot, and found an availability of forage of $453 \mathrm{~kg} / \mathrm{ha}$ on the fourteenth week and $428 \mathrm{~kg} / \mathrm{ha}$ on the sixteenth week of the experimental period, and concluded that an availability of DM higher than $1,000 \mathrm{~kg}$ may not be the most important factor in the reduction of animal intake.

The intake of animals that were given different supplementation levels can be considered adequate, particularly if we consider findings from other studies with goats in pasture. In their evaluation of the effect of supplementation with urea on the intake of goats with an average weight of $18.76 \mathrm{~kg}$ in Mexican native pastures, Galina et al. (2004) observed dry matter intake varying between 2.8 and $3.2 \%$ of $\mathrm{LW}$, with a total consumption of forage varying from 475.63 to $513.61 \mathrm{~g} /$ day, whereas the DMI values obtained in the present study varied from 539.43 to $953.36 \mathrm{~g} /$ day, from 2.51 to $3.45 \%$ of $\mathrm{LW}$ and from 50.43 to $76.66 \mathrm{~g} / \mathrm{kg}^{0.75} /$ day. These results can be considered significant, compared with those found by Ramirez et al. (1995), who assessed nutrient intake by sheep in pastures with buffel grass (Chechrus Ciliaris), with animals reaching an average intake of $53.7 \mathrm{~g} / \mathrm{kg}^{0.75} / \mathrm{day}$.

Quadratic effect of supplementation was found, and according to the estimate of the equation the maximum point for the replacement coefficient occurred when supplementation reached the level of $0.74 \%$ of LW (Figure 3 ).

Table 4 - Intake of roughage and concentrate by goats finished in nature pasture with different supplementation levels

\begin{tabular}{|c|c|c|c|c|c|c|c|c|c|}
\hline \multirow{2}{*}{$\begin{array}{l}\text { Supplementation } \\
\text { (\% of live weight) }\end{array}$} & \multicolumn{3}{|c|}{ Intake (g/day) } & \multicolumn{3}{|c|}{ Intake (\% of live weight) } & \multicolumn{3}{|c|}{ Intake (g/kg ${ }^{0.75} /$ day) } \\
\hline & Forage & Concentrate & Total & Forage & Concentrate & Total & Forage & Concentrate & Total \\
\hline 0.0 & 539.43 & & 539.43 & 2.51 & & 2.51 & 50.43 & & 50.43 \\
\hline 0.5 & 508.84 & 123.75 & 632.59 & 2.41 & 0.5 & 2.91 & 46.31 & 11.10 & 57.41 \\
\hline 1.0 & 510.07 & 217.50 & 727.57 & 2.34 & 1.0 & 3.34 & 52.75 & 21.51 & 74.26 \\
\hline 1.5 & 530.86 & 402.25 & 953.36 & 1.95 & 1.5 & 3.45 & 45.59 & 31.07 & 76.66 \\
\hline
\end{tabular}

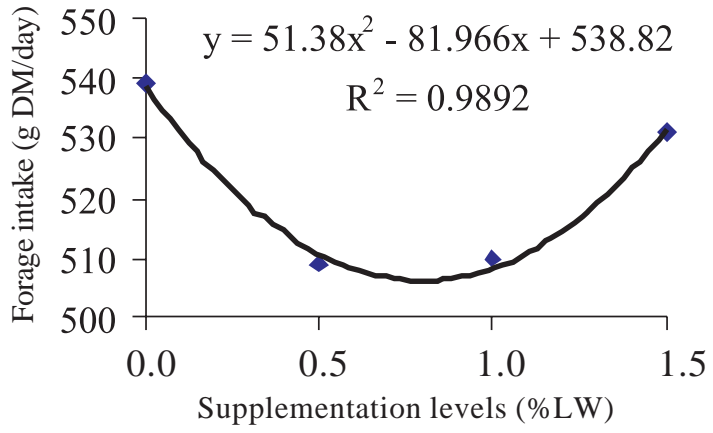

Figure 2 - Forage intake per goats finished in native pasture with different supplementation levels.

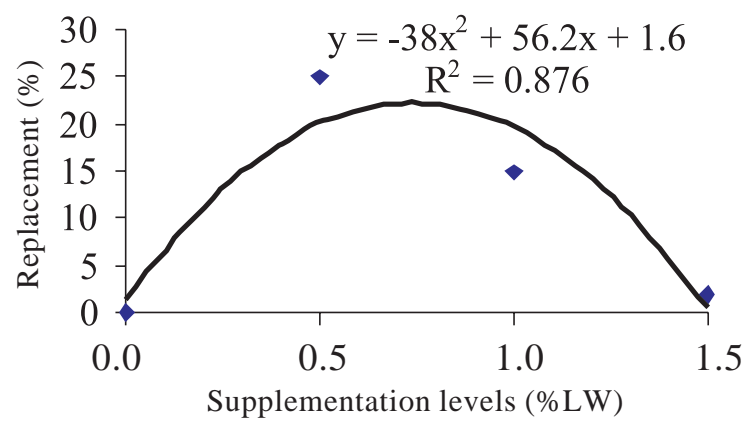

Figure 3 - Coefficient of replacement of dry matter intake of forage with concentrate. 
Reis et al. (2001) affirm that one of the purposes of supplementation in pasture is to correct deficiencies of nutrients in forage, and that the value of the replacement coefficient may have a negative value, in a stimulus to the consumption of forage provoked by the supplement.

The efficient use of foraging plants by animals depends on various factors, of which it is worth mentioning the quality and quantity of available forage and animal potential (Santos \& Costa, 2006). In this context, the average values of CP (crude protein), NDF (neutral detergent fiber) (Table 2) and digestibility (Figure 1) varied from 6.62, 79.15 and 65.06 for grasses and 11.38, 64.69 and 64.62 for dicotyledons. Despite the high contents of neutral detergent fibers, no digestibility problem was noticed, which according to Animut et al. (2005) does not occur when forage digestibility is greater than $50 \%$. DM availability is above $1,000 \mathrm{~kg}$ of $\mathrm{DM} /$ ha for paddocks occupied with 4, 6 and 8 animals, particularly in native pastures with high diversity of foraging species (Araújo Filho et al., 1996) where animal selectivity is a determinant factor in the botanical and chemical diet composition (Gihad, 1976).

In a study with goats in natural caatinga, Pfister (1983) found LW contents higher than $11 \%$ in the diet of sheep, even in the dry season. Contents of $14.6 \%$ and $17.7 \%$ were found in the season of most intense rainfalls. Araújo Filho et al. (1996) found crude protein levels of 9.3\% in the dry season, $12.6 \%$ in the transition period between rainy/dry seasons and 17.1 in the transition from the dry to the rainy season, indicating the foraging potential of the caatinga vegetation.

Final weight, total gain and daily weight gain were positively and linearly influenced $(\mathrm{P}<0.05)$ by the supplementation levels (Table 5), with an increase of 3.12, 2.88 and $0.034 \mathrm{~kg}$, respectively for each percentage point increase that resulted from supplementation, thus reflecting DM intake by animals which is required to meet animal demands of maintenance and production (Gomide, 1993).

The good performance of animals without supplementation may be credited to the high availability and quality of forage, with the grasses having initial values of $1,102.89 \mathrm{~kg} / \mathrm{ha}$ of DM, 9.8\% of LW and $65.98 \%$ of DM digestibility. Concerning the dicotyledons, which are more appreciated by goats, compared with grasses, values of $1,759.46 \mathrm{~kg} / \mathrm{ha}$ of DM with $12.42 \%$ of LW and digestibility of $66.78 \%$, respectively, were found.

It is possible to relate animal performance to the total DM and volume intake results, as well as the additive/ replacement effect, because the supplementation had quadratic effect, which allows us to estimate a reduction in DM volume intake of up to $0.8 \%$ of supplementation, and a higher replacement level when supplementation corresponds to $0.74 \%$ of live weight.

In their assessment of the different levels of supplementation in the rebreed of crossbred steer in Brachiaria brizantha pastures in the Amazon region, Goes et al. (2005) found that the animals were given $0.5 \%$ and $1.0 \% \mathrm{LW}$ supplementation, had a similar live weight at the end of the studied periods, and obtained the highest weight gains in the period of climate transition (wintersummer). Brum et al. (2008) in a research conducted to assess animal performance and forage characteristics in food systems for rebreed of sheep in pasture found $0.131 \mathrm{~kg} /$ day for average daily weight gain (ADWG). While supplementing sheep of Santa Inês breed with 1.5\% and $1 \%$ of LW, Dantas et al. (2008) encountered ADWG values of 192 and $148 \mathrm{~g}$, respectively, and $90 \mathrm{~g}$ for non supplemented animals; this result is attributed to the availability and digestibility of forage.

Taking into consideration the changes in the availability and quality of the native pasture throughout the year, particularly from May to August, it may be important to stress how the animals responded to these variations in the experimental period. Concerning the periods (days) assessed, the period corresponding to 28 days was the one of greatest gain in weight, totaling $208 \mathrm{~g}$, whereas the lowest average gain of weight was $127 \mathrm{~g}$, after 84 days of experiment (Table 6). Although the equations obtained have low determination coefficients, a linear behavior was found for supplementation level and a quadratic behavior for period.

The values of daily weight gain observed and those predicted by the supplementation equation at the

Table 5 - Performance of crossbred goats finished in native pasture with different supplementation levels

\begin{tabular}{|c|c|c|c|c|c|c|}
\hline \multirow[t]{2}{*}{ Item } & \multicolumn{4}{|c|}{ Supplementation level (\% of live weight) } & \multirow[t]{2}{*}{ Regression equation } & \multirow[t]{2}{*}{$\mathrm{R}^{2}$} \\
\hline & 0.0 & 0.5 & 1.0 & 1.5 & & \\
\hline Initial weight (kg) & 16.71 & 15.75 & 16.67 & 16.50 & $\hat{Y}=16.41$ & 0.00 \\
\hline Total gain $(\mathrm{kg})$ & 8.64 & 9.83 & 12.30 & 12.67 & $\hat{Y}=8.66+2.88 x$ & 0.35 \\
\hline Average daily weight gain (kg) & 0.103 & 0.117 & 0.147 & 0.151 & $\hat{Y}=0.103+0.034 x$ & 0.35 \\
\hline
\end{tabular}

$\hat{Y}=$ dependent variable; $x=$ independent variable; $r^{2}=$ coefficient of determination. 
experimental periods for levels $0.0,0.5,1.0$ and $1.5 \%$ of supplementation were: 142 and 138.95; 153 and 158.10; 178 and 177.25; 198 and 196.4, which provided efficiency to the equation, particularly to the levels of supplementation of 1 to $1.5 \%$ of the LW. Concerning the prediction of weight gain at each period, it became more disperse for the observed periods. However, the quadratic equation allows us to better predict the gain weight of animals at days 27.47 of supplementation.

The reduction in the DWG of animals in all treatments has a strong relationship with the quality and availability of grasses and dicotyledons, since at the final stage of the experiment grasses accounted for $88.6 \%$ (1494.8 kg/ha) and had a $80.21 \%$ NDF (neutral detergent fibers) content and only 5.71\% of LW in DM, compared with herbaceous dicotyledons, which, despite their $13.43 \% \mathrm{LW}$, accounted for only $12.4 \%$ (236.7 kg/ha) of all the available DM. These data somewhat corroborate the assertion of Van Soest (1994), that low level of protein is a limiting factor in the growth of ruminal microorganisms, causing slow degradation of ingested forage, which, associated to high contents of NDF (Mertens, 1997), induce the negative correlation between DM intake and the content of NDF (Silva et al., 2003), longer retention of food in the rumen and lower nutrient intake by the animals, resulting in low animal performance even for goats (Silanikove, 2000), which are less affected compared with other ruminant species when fed on nutrient deficient diets.

Table 6 - Gain daily live weight per period of crossbred goats finished in native pasture with different supplementation levels

\begin{tabular}{|c|c|c|c|c|c|}
\hline \multirow[t]{2}{*}{ Period } & \multicolumn{4}{|c|}{ Supplementation (\% of live weight) } & \multirow[t]{2}{*}{ Average } \\
\hline & 0.0 & 0.5 & 1.0 & 1.5 & \\
\hline $0-14$ & 148 & 137 & 186 & 226 & 173 \\
\hline $0-28$ & 176 & 208 & 203 & 250 & 208 \\
\hline $0-42$ & 156 & 167 & 193 & 198 & 177 \\
\hline $0-56$ & 146 & 147 & 180 & 192 & 165 \\
\hline $0-70$ & 123 & 140 & 157 & 170 & 146 \\
\hline $0-84$ & 103 & 117 & 147 & 159 & 127 \\
\hline Average & 142 & 153 & 178 & 198 & \\
\hline
\end{tabular}

\section{Conclusions}

The availability of forage associated to its nutritional quality (chemical composition and digestibility) is a determinant factor on the effect of supplementation on intake and productive performance of goats finished in native pasture. The supplementation in pasture allows better animal performance. A replacement effect (roughage by concentrate) occurs at levels up to $0.74 \%$ of $\mathrm{LW}$; however, above $0.8 \%$ of $\mathrm{LW}$ it stimulated the total intake of dry matter. Therefore, under these experimental conditions, the finishing of F1 (Boer $\times$ females of no defined breed) goats in pasture with supplementation of 1.0 to $1.5 \%$ of live weight is recommended.

\section{References}

AGRICULTURAL AND FOOD RESEARCH COUNCIL - AFRC. The nutrition of goat. Report Nutrition Abstract Revision (Series B), Aberdeen, 1998. 116p.

ANIMUT, G.; GOETSCH, A.L.; AIKEN, G.E. et al. Grazing behavior and energy expenditure by sheep and goats cograzing grass/forb pastures at three stocking rates. Small Ruminat Research, v.59, p.191-201, 2005.
ARAÚJO FILHO, J.A.; CARVALHO, F.C.; GARCIA, R. et al Efeitos da manipulação da vegetação lenhosa sobre a produção e compartimentalização da fitomassa pastável de uma caatinga successional. Revista Brasileira de Zootecnia, v.31, n.1, p.11-19, 2002.

ARAÚJO FILHO, J.A.; GADELHA, J.A.; LEITE, E.R. et al. Composição botânica e dieta de ovinos e caprinos em pastoreio combinado na região dos Inhamuns, Ceará. Revista Brasileira. de Zootecnia, v.25, n.3, p.383-395, 1996.

ARAÚJO FILHO, J.A. Manpulação da vegetação lenhosa da Caatinga para fins pastoris. Sobral: EMBRAPA-CNPC, 1991. 18p. (Circular técnica, 11).

BERCHIELLI, T.T.; ANDRADE, P.; FURLAN, C.L. et al. Avaliação de indicadores internos em ensaios de digestibilidade. Revista Brasileira de Zootecnia, v.29, n.3, p.830-833, 2000a.

BERCHIELLI, T.T.; FURLAN, C.L.; AROEIRA, J.L.M. et al. Estimativa do consumo de matéria seca de vacas em lactação em pastejo rotativo em capim coastcross (Cynodon Dactylon, (L.) Pers cv. coast cross). Acta Scientiarium, v.22, n.3, p.843-849, 2000b.

BONAGURIO, S.; PEREZ, J.R.O.; GARCIA, I.F.F. et al. Qualidade da carne de cordeiros Santa Inês puros e mestiços com Texel abatidos com diferentes pesos. Revista Brasileira de Zootecnia, v.32, n.6, p.1562-1570, 2003.

BRUM, M.S.; QUADROS, F.L.F.; MATINS, J.D. et al. Sistemas de alimentação para recria de ovinos a pasto: avaliação do desempenho animal e características da forragem. Revista Ciência Rural, v.8, n.1, p.191-198, 2008.

CARVALHO JR., A.M.; PEREIRA FILHO, J.M.; SILVA, R.M. et al. Efeito da suplementação nas características de carcaça e dos 
componentes não-carcaça de caprinos F1 Boer x SRD terminados em pastagem nativa. Revista Brasileira de Zootecnia, v.38, n.7, p.1301-1308, 2009.

CRABTREE, J.R.; WILLIAMS, G.L. The volumtary intake and utilization of roughage-concetrate diets by sheep.1. Concentrate supplementes for hay and straw. Animal Production, v.13, n.1, p.71-72, 1971.

DANTAS, A.F.; PEREIRA FILHO, J.M.; SILVA, A.M.A. et al. Características da carcaça de ovinos Santa Inês terminados em pastejo e submetidos a diferentes níveis de suplementação. Ciência e Agrotecnologia, v.32, p.1280-1286, 2008.

FORBES, J.M. Voluntary food intake and diet selection in farm animals. Wallington: $\mathrm{CAB}, 1995.532 \mathrm{p}$.

GALINA, M.A.; GUERRERO, M.; PUGA, C.D. et al. Effects of slow-intake urea supplementation on goat kids pasturing natural Mexican rangeland. Small Ruminant Research, v.55, p.85-95, 2004.

GIHAD, E.A. Studies on the nutritional value of pasture species in Zambia, African Journal of Agricultural Science, v.41, n.4, p.335-339, 1976.

GOES, R.H.T.B.; MANCIO, A.B.; LANA, R.P. et al. Recria de novilhos mestiços em pastagem de Brachiaria brizanta, com diferentes níveis de suplementação, na região amazônica. Consumo e parâmetros ruminais. Revista Brasileira de Zootecnia, v.34, n.5, p.1730-1739, 2005.

GOMIDE. J.A. Produção de leite em regime de pasto. Revista Brasileira de Zootecnia, v.22, n.4, p.591-613, 1993.

GRAHAM, P.; LANGFORD, C.M.; BELL, A.K; How pasture characteristics influence sheep production. Agnote: NSW Agriculture, 1993. 5p.

KABEYA, K.S.; PAULINO, M.F.; DETMANN, E. et al. Suplementação de novilhos mestiços em pastejo na época de transição água-seca; desempenho produtivo, Características físicas de carcaça, consume e parâmetros ruminais. Revista Brasileira de Zootecnia, v.31, n.1, p.213-222, 2002.

KANANI, J.; LUKEFAHR, S.D.; STANKO, R.L. et al. Evaluation of tropical forage (Medicago sativa,Dolichos lablab, Leucaena leucocephala and Desmanthus bicornutus) for growing goats. Small Ruminant Research, v.65, p.1-7, 2006.

LEÃO, M.M.; ANDRADE, I.F.; BAIÃO, A.A.F. et al. Níveis de suplementação de novilhos mestiços mantidos a pasto. Ciência Agrotécnica, v.29, n.5, p.1069-1074, 2005.

MARQUES, M.R; BELO, C.C. Estudo do comportamento alimentar de ovelhas Serra da Estrela em condições de pastoreio diferido/ rotacional. Influência da suplementação energética da erva na quantidade e qualidade do leite produzido. Revista Pastagens e Forragens, v.22, p.19-36, 2001.

MERTENS, D.R. Creating a system for meeting the fiber requirements of dairy cows. Journal of Dairy Science, v.80, n.7, p.1463-1481, 1997.
NEIVA, J.M.N.; SOARES, A.N.; MORAES, S.A. et al. Farelo de glúten de milho em dietas para ovinos em confinamento. Revista Ciência Agronômica, v.36, n.1, p.11-117, 2005.

PEREIRA FILHO, J.M.; ARAÚJO FILHO, J.A.; CARVALHO, F.C. et al. Disponibilidade de fitomassa do estrato herbáceo de uma caatinga raleada submetida ao pastejo alternado ovino-caprino. Livestock Research for Rural Developement, v.19, n.1, 2007. Available at: <http://www.cipav.org.co/lrrd/lrrd19/1/ pere19002.htm>. Accessed on: March 11, 2008.

PFISTER, J.A. Nutrition and feeding behavior of oat and sheep grazing deciduous shrubswoodland in Northeastern Brazil. 1983. 130f. Thesis (Ph.D. in Range Science) - Utah State University, Utah.

PROHMANN, P.E.F.; BRANCO, A.F.; JOBIM, C.C et al. Suplementação de bovinos em pastagem de coastcross (Cynodon dactylon (L.) Pers) no verão. Revista Brasileira de Zootecnia, v.33, n.3, p.792-800, 2004.

RAMIREZ, R.G.; ALONSO, D.S.; HERNÁNDEZ, G.et al. Nutrient intake of range sheep on a buffelgrass (Cenchrus ciliaris) pasture. Small Ruminat Research, v.17, p.123-128, 1995.

REIS, W.; JOBIM, C.C; MACEDO, F.A.F et al.Caracteristica de carcaça de cordeiros alimentados com dietas contendo grãos de milho conservados em diferentes formas. Revista Brasileira de Zootecnia, v.30, n.4, p.1308-1315, 2001.

SANTOS, P.M.; COSTA, R.Z.M. Manejo de pastagem de capimtanzânia. São Carlos: EMBRAPA-CPPSE, 2006. 26p. (Documentos, 52).

SILANIKOVE, N. Effects of heat stress on the welfare of extensively managed domestic ruminants. Livestock Producion Science, v.67, p.1-18, 2000 .

SILVA, A.M.A.; SILVA SOBRINHO, A.G.; TRINDADE, I.A.C.M. et al. Food intake and digestive efficiency in temperate wool and tropic semi-arid hairlambs fed different concentrate:forage ratio diets. Small Ruminant Research, v.55, p.107-115, 2003.

SILVA, D.J.; QUEIROZ A,C. Análise de alimentos: métodos químicos e biológicos. Viçosa, MG: UFV, 2002. 166p.

SILVA, R.M.; PEREIRA FILHO, J.M.; SILVA, A.L.N. et al. The effect of supplementation on the tissue composition of the commercial cuts of cross-bred F1 (Boer $\times$ SPRD) finished in native pasture. Revista Brasileira de Zootecnia, v.39, n.6, p.1353-1358, 2010.

STATISTICAL ANALYSES SYSTEM - SAS. The SAS system for windows. Version 8.0. Cary, 1999. (CD-ROM).

VAN SOEST, P.J. Nutritional ecology of the ruminant. Ithaca: Cornell University Press, 1994. 476p.

WALDO, D.R. Effect of forage quality on intake and forage concentrate interactions. Journal of Dairy Science, v.69, n.2, p.617-631, 1986. 